\title{
The Relationship Between Multilateral Environmental Agreements and the WTO Regime: The Way Forward
}

\author{
Endryas Tekalegn \\ College of law, Direddawa University, PO box 1362, Diredawa Ethiopia
}

\begin{abstract}
Conflict exists between World Trade Agreement (WTO) and Multilateral Environmental Agreements (MEAs). This is because governments when negotiating MEAs they include measures which sanction trade coercion and create provisions to restrict trade despite WTO rules to which the same Governments subscribe, does not permit such use of trade measures. After analyzing the relationship between the WTO and MEAs, this writing argues that the growing global interconnectedness, both in economic and environment, needs coherence and coordination in trade and environmental policies, rules, and institutions.
\end{abstract}

Keywords: WTO, MEAs, GATT, Non Discrimination, MFN

DOI: $10.7176 /$ IAGS/77-03

Publication date: November $30^{\text {th }} 2019$

\section{Background}

When governments negotiate MEAs they include measures which sanction trade coercion and create provisions to restrict trade which thereby results in conflict between the WTO rules and MEAs. This generates problems because the WTO, to which the same Governments subscribe, does not permit such use of trade measures. ${ }^{1}$

This conflict between the WTO laws, the Panel \& the Appellate body on the one hand and MEAs and the mechanisms provided for resolving disputes in MEAs on the other, requires critical analysis of the relationship between the WTO and MEAs to thereby provide what will be done to reconcile the conflicts that would exist amongst the two as disputes and conflicts were inevitable.

Therefore, this writing analyses the relationship between the WTO and MEAs. In doing so, the first part discusses the relationship and importance of the relation between the two. The second part discusses the role of trade measures within MEA's with emphasis on four MEAs. Then the third part discusses the implication of trade measures on the economic, legal and political arena for global governance. And finally provide some concluding remarks.

\section{Defining the relationship and the importance of the relationship between WTO and MEAs}

Multilateral Environmental Agreements (MEAs) have emerged as an important means for countries to tackle environmental problems, particularly those regional or global in scope. Several MEAs contain provisions for measures to control trade, in order to prevent damage to the environment or as a tool to encourage compliance with their objectives.

Measures taken pursuant to MEAs could give rise to questions of consistency with certain WTO rules, such as the non-discrimination principle, or the prohibition of quantitative restrictions. Under GATT ${ }^{2}$ Article I, any advantage or privilege granted by a country to any product originating in any other country shall be accorded to like products originating in the territories of all other WTO Members. Pursuant to GATT Article III, WTO Members must not discriminate between imported and domestic like products. Under GATT Article XI, no prohibitions or restrictions other than duties, taxes or other charges such as quotas, import or export licenses shall be applied on the import or export of any product.

The very possible situation of conflict could materialize where an MEA authorizes trade between its parties in a specific product, but bans trade in that very same product with non-parties (hence, an inconsistency with the Most Favored Nation (MFN) clause, which requires countries to grant equivalent treatment to "like" imported products).

The other possible situation is the GATT exception ${ }^{3}$, in which case, in the context of a dispute on the application of a trade measure under an MEA, the respondent could invoke a defense under GATT.

To this effect, clarifying the relationship between the two is an important task and the desire to clarify the MEA-WTO relationship is not new as the United Nations Conference on Environment and Development (UNCED) in Rio de Janeiro, Brazil in $1992,{ }^{4}$ and trade negotiators at the Uruguay sought to clarify the

\footnotetext{
*The Author has got Advanced Diploma in Law (Jimma University, School of Law) LLB (Haramatya University, School of Law), LLM in international economics and business law (Haramaya University, School of Law), currently, Lecturer in Diredawa University School of law. ${ }^{1}$ United Nations Conference on Trade and Development, Trade and environment review, commentaries, UN New York April 2004 .

${ }^{2}$ General Agreement on Tariffs and Trade, Oct. 30, 1947, 61 Stat. A-11, 55 U.N.T.S. 194 [hereinafter GATT]

3 See Article XX of GATT

${ }^{4}$ See Duncan Brack and Kevin Gray, Multilateral Environmental Agreements and the WTO, Report, the Royal Institute of international
} 
relationship between MEA trade measures and the rules of the multilateral trading system. ${ }^{1}$

The relation of MEAs and WTO comes from the very inclusion of "sustainable development" clause in the WTO Agreement's preamble; the "environmental" exceptions in the General Agreement on Tariffs and Trade (GATT) Article XX(b) and (g) and other various environment relevant provisions in WTO laws. ${ }^{2}$

In 2001, the discussions between WTO members culminated in a decision by trade ministers to include negotiations on the relationship between WTO rules and "specific trade obligations" set out in MEAs in the WTO Doha Ministerial Declaration. ${ }^{3}$

Then after, Paragraph 31 (i) of the Doha Development Agenda calls for negotiations on the relationship between existing WTO rules and specific trade obligations set out in MEAs. ${ }^{4}$

Therefore, as provided here in above, the MEA-WTO debate has been in existence since the establishment of the WTO, without much sign of progress.

\section{Analyzing the role and Implications of trade measures on the "economic, legal political arena of global governance}

Trade measures tends to be used in the trade policy context to mean any policy instrument which attaches requirements, conditions or restrictions on imported or exported products or services themselves, or the process of their importation or exportation. ${ }^{5}$ Marceau explains trade measures are used to regulate trade in environmentally harmful products, and to create a regulatory framework to manage and minimize environmental risk. ${ }^{6}$ This author in her other work further explains trade measure as an important armor of members. ${ }^{7}$ Thus, trade measures are generally understood as any policy instrument that attaches requirements, conditions or restrictions on imported or exported products or services themselves or the process of their importation or exportation. ${ }^{8}$

So, trade measures can range from reporting standard, labeling requirements, notification and consent procedure, import export ban to taxes or government procurements.

Taking this as a guise, the WTO Secretariat lists 20 MEAs from 250 MEAs $^{9}$ containing potential trade measures, though some of these are regional rather than global agreements, and protocols are included along with their parent conventions under single headings though for most purposes it makes more sense to treat them as different agreements. ${ }^{10}$

Members to MEAs include trade measures in those treaties not because they want to make fun of it rather they have destined with certain role and functions.

- One of the more common roles and function of trade measures within an MEA is to control trade as a source of environmental damage. ${ }^{11}$ MEAs are intended to control trade practices where trade is considered a source of environmental damage. Without trade measures or restrictions countries cannot prevent the cross-border transport and entry of regulated items, such as hazardous waste or endangered species. This type of trade measure is incorporated in a number of MEAs. This type of trade measure is incorporated in a number of MEAs. For example, CITES prohibits trade in listed endangered species in the absence of export permits or import licenses, while the Basel Convention requires prior notification and consent from import, export and transit states for the shipment of hazardous waste. ${ }^{12}$

- The other role of trade measures within MEAs is to induce compliance of parties ${ }^{13}$. Several trade measures are

affairs, sustainable development program and IISD, Sep. 2003 page 4 https://www.iisd.org/pdf/2003/trade meas wto.pdf. Last Visited $15 / 10 / 2019$

${ }^{1}$ Douglas Jake Caldwell, Multilateral Environmental Agreements and the GATT/WTO Regime, Trade, Health, and Environment Program, Revised Version, April 1998

2 See Annick E. Brunner, conflicts between international trade and multilateral environmental agreements, Page 79 http://digitalcommons.law.ggu.edu/cgi/viewcontent.cgi?article=1031\&context=annlsurvey Last Visited 15/10/2019

${ }^{3}$ WTO, Trade and environment at the WTO, the relationship between MEAS and the WTO, page 39. See also WTO Doha Ministerial Declaration, WT/MIN (01)/DEC/1, paragraph 6.

${ }^{4}$ Ibid (Trade and environment at WTO) page 40

${ }^{5}$ Trade measures in Multilateral Environmental Agreements: Synthesis Report of Case studies, Joint Working Party on Trade and Environment Organization for Economic Co-operation and Development, COM/ENV/TD(98)127/FINAL,Feb. 1999

${ }^{6}$ See Gabrielle Zoe Marceau, Conflicts of norms and conflicts of jurisdictions: the relationship between the WTO agreement and MEAs and other treaties, Journal of World Trade, 2001, vol. 35, no. 6, pp. 1095

${ }^{7}$ MARCEAU, Gabrielle Zoe. A call for coherence in international law : praises for the prohibition against "Clinical Isolation" in WTO dispute settlement. Journal of World Trade, 1999, vol. 33, no. 5, at pp 104

${ }^{8}$ Yen H. Trinh, moving the negotiation on trade measures in multilateral environmental agreements forward, part A, page 96 http://pon.harvard.edu/wp-content/uploads/images/posts/Art.3-Part-B.pdf Last visited 16/9/2019

${ }^{9}$ See WTO, Environment: Multilateral Environmental Agreements, the Matrix on Trade Measures Pursuant to Selected Multilateral Environmental Agreements, https://www.wto.org/english/tratop e/envir e/envir matrix e.htm Last Visited 16/9/2019

${ }^{10}$ See The Matrix on Trade Measures Pursuant to Selected Multilateral Environmental Agreements, WT/CTE/W/160.Rev.2, TN/TE/S/5, 25 April 2003

${ }^{11}$ William A. Kerr and James D. Gaisford, Handbook on International Trade Policy, Edward Elgar Publishing Limited, 2007 pp 431

${ }^{12}$ Ibid

${ }^{13}$ Ibid pp 432, and see also Veena Jha and Ulrich Hoffmann, Achieving objectives of multilateral environmental agreements: a package of 
intended to impede nonparties from taking advantage of environmental gains resulting from party commitment. This free-riding problem is usually solved by trade bans between nonparties and parties that have regulated goods. Some MEAs such as CITES induce compliance by imposing trade sanctions in which case trade suspension of Italy in endangered spices of fauna and flora was essential for Italy's compliance in $1992^{1}$. The same successful action was taken against Thailand, El-Salvador, United Arab Emirates Equatorial Guinea other countries. ${ }^{2}$

- A third common role of trade measures within MEAs aims to control the role of non-parties as transit countries for illegal trade under MEAs and thus, secure greater compliance with MEAs. It provides a means of enforcing the MEA by forbidding trade with non-parties or parties that do not comply with the MEA. Therefore, the trade restrictions, usually trade bans, are aimed at preventing these countries or industries from gaining a competitive advantage in trade with states controlled by the MEA (the problem of environmental leakage arising from less than universal participation) and thereby maximize their participation in the MEA ${ }^{3}$.

Given this roles, and though many treaties incorporate trade measure as provided somewhere above, it is somewhat convincing to say few words on three MEAs and consider at least how they have used trade measures to achieve their objectives and thereby overlaps with WTO rules.

\section{i. CITES}

With 175 parties including the United States, the Convention on International Trade in Endangered Species of Wild Fauna and Flora (CITES) has been considered an effective MEA since entering into force in 1975.

Appendix I contain species threatened with extinction and which are or may be affected by international trade. Appendix I includes approximately 600 animals and 300 plant species. Trade in Appendix I species for commercial purposes is basically prohibited, authorized only in exceptional circumstances. While trade in Appendix II species is governed by export permits (or re-export certificates), issuance of which is subject to both a finding of non-detriment and legal acquisition of the species. The granting of an import permit is not a condition under CITES for trading in Appendix II species, but is in fact required by most OECD countries under their domestic implementing legislation. Appendix III covers 200 animals and six plants which are protected in a country having requested assistance of other CITES parties in controlling the trade. ${ }^{4}$

\section{ii. Montreal Protocol}

With and initial ratification by 163 countries, the Montreal Protocol is generally considered the most effective MEA. The Protocol bans trade in ozone-depleting substances (ODS) with non-members, and strictly controls production and trade of ODS by members. In fact, the agreement not only applies to ODS but could also apply to products made with these substances (such as semiconductors). The Montreal Protocol has very sophisticated tools to obtain compliance from both parties and non-parties, and the agreement is credited with having significantly reduced the threat from ODS. ${ }^{5}$ The Protocol provides for the imposition of trade sanctions in the event of non-compliance and the ability of the Montreal Protocol to address the non-party problem is a key to its effectiveness.

\section{iii. The Basel Convention}

Convention on the Control of Trans-boundary Movements of Hazardous Wastes and Their Disposal (The Basel Convention) which entered into force in 1992 now has 141 parties and regulates the flow of trade in hazardous substances. This Convention requires parties intending to export hazardous waste to notify the importing country and obtain consent through a "prior informed consent" procedure. Parties to the agreement thus have the right to refuse importation. Trade between parties and a non-party is prohibited, unless the nonparty has measures in place as effective as that required by the Convention.

In general, trade measures have the role of achieving the MEA objectives that includes; encouraging universality of membership, preventing opportunities for trans-shipment; bolstering compliance, and action against noncompliance. And each of these makes an international Environmental treaty work.

\section{Experience of WTO or other relevant dispute settlement bodies}

Once it was discussed above about the role of trade measures within MEAs, the next issue would be the interrelationship between MEAs with trade measures and the multilateral trading system. Could the use of MEA trade measures for environmental reason against WTO members considered as violation of WTO law?

As said somewhere above, the WTO's nondiscrimination principle embodied under Article I and III of the

trade measures and positive measures, Elucidated by results of developing country case studies UNCTAD/ITCD/TED/6 pp 25

${ }^{1}$ See supra note 5 page 14, see also United Nations Conference on Trade and Development, Trade and environment review, commentary, UNCTAD/DITC/TED/2003/4, UN New York and Geneva April 2004. page 107

2 See The WTO and MEAs-Time for a Good Neighbor Policy https://www.wilsoncenter.org/sites/default/files/paper.pdf Last visited $15 / 9 / 2019$

${ }^{3}$ See supra note 18 page 432 and also supra note 15 at page 98

${ }^{4}$ OECD, trade measures in multilateral environmental Agreements, OECD publication service 1999 page 16-17

${ }^{5}$ Ibid at page $64-68$ 
GATT requires WTO members not to discriminate between their trading partners or between imported and locally produced products. MEAs however, discriminate between imports and domestic goods as well as between parties and nonparties according to the assessment of their environmental performance. Article XI of GATT stipulates that no prohibition or restriction other than duties taxes or charges shall apply on imported and exported goods. While in contrast, MEAs requires quantitative restrictions.

And truly enough, potential incompatibility of MEA trade measures with WTO laws is undeniable. So, what is then?

To clearly underpin this discussion, it is better to consider the possible conflict that exists on the application of trade measures under MEAs.

Marceau has argued that the alleged conflicts between the WTO and MEA trade restrictions can be analyzed in two situations. The first situation that involves conflict is where the MEA is adopted by both WTO disputants. And the second situation is where MEA that has not been adopted by both WFO disputants. ${ }^{1}$

The alleged conflict can be dealt, according to Marceau, by interpreting the WTO agreements so as to avoid conflict with MEAs and further argued that a trade measure required by the terms of the MEA would be "presumed" to satisfy the requirements of Article XX and for actions to be taken to promote environmental goals, even in the absence of an MEA on the subject-matter. ${ }^{2}$

If interpretation fails to reconcile the WTO provision and MEA, Article 30 and 31 of the Vienna Convention and lex specialis principle provides the way out. In that that; when the provisions of the two treaties concerning the same subject matter conflict, as between parties to both treaties, the later-in-time prevails, unless one treaty explicitly notes otherwise and good faith shall be taken in to account. ${ }^{3}$

Shaw has provided that the process of interpretation is a judicial function. ${ }^{4}$ But the question is where this assessment will be taken and which organ will determine it.

Marceau argues that "this assessment will not take place in a vacuum but will most probably be dealt before WTO panels and the Appellate Body, since Article 23 of the DSU "attracts" jurisdiction in favor of WTO adjudicating bodies to the exclusion of other fora. Therefore... WTO adjudicating bodies-with a delegated power to interpret WTO provisions in their examination of whether those provisions have been violated have the legal capacity to recognize that a WTO provision has been superseded by another treaty provision; and if so, what type of conclusion they can arrive at in light of Articles 3 and 19 of the DSU, which prohibit panels and the Appellate Body from adding to or diminishing rights and obligations pursuant to the WTO treaty \{Emphasis added $\}^{5}$

This argument of Marceau is correct by the fact that within the section on Conclusions and Recommendations of the December 1996 Report of the WTO Committee on Trade and Environment WTO Members have stated their view that if a dispute arises between WTO members, Parties to an MEA, over the use of trade measures they are applying between themselves pursuant to the MEA, they should consider trying to resolve it through the dispute settlement mechanisms available under the MEA. ${ }^{6}$

Thus, in the event that a dispute were in fact to proceed under the WTO dispute settlement procedure, the Dispute Settlement Panel would be charged with deciding the issue in the context of the GATT and the relevant WTO Agreements, using "customary rules of interpretation of public international law" where appropriate to clarify WTO provisions Article 3(2) of the Dispute Settlement Understanding and the Appellate Body has stated that these agreements must not be read "in clinical isolation of public international law".?

Despite this however, the potential of forum shopping is also inevitable where parties initiate a dispute both under MEA and the WTO where it arises from the same factual situation. This problem occurred in the swordfish dispute between Chile and the EU in 2000, whereby the EU threatened to raise the issue through the WTO, while Chile has appealed to the International Tribunal on the Law of the Sea. ${ }^{8}$ Although from the point of view of academics poised to write about the clash of dispute forums, the case was resolved by agreement between the two countries on 25 January $2001 .^{9}$

The next question after determining the possible ways by which WTO can entertain cases relating to MEAs, is look whether there are cases entertained by the panel or the appellate body or other organs relating to MEAs.

\footnotetext{
${ }^{1}$ MARCEAU, supra note 13 page 1097

${ }^{2}$ Ibid page 1098-1099

${ }^{3}$ See the Vienna Convention on the Law of Treaties, May 22, 1969

${ }^{4}$ see Malcolm N. Shaw, international law $6^{\text {th }}$ edi. Cambrige University press, 2008 page $932-935934$

${ }^{5}$ MARCEAU, supra note 13 page 1100

${ }^{6}$ See WTO Press Brief, Trade and environment, https://www.wto.org/english/thewto_e/minist_e/min96_e/environ.htm Last accessed $18 / 9 / 2019$

${ }^{7}$ See Appellate Body in Standards for Reformulated and Conventional Gasoline, WT/DS2/AB/R, 29 April 1996 (US Gasoline) p 18

${ }^{8}$ See supra note 5 page 29

${ }^{9}$ Duncan Brack, International forums for non-compliance and dispute settlement in environment-related cases, The Royal Institute of international affairs, Mar. 2001 page 3, https://www.ippc.int/static/media/files/publications/en/1182350929558_Noncompliance_Brack.pdf Last visited18/9/2019
} 


\section{WTO}

Three that arose during GATT (the two tuna-dolphin cases, in 1991 and 1994, and the CAFE case dealt with US taxes on imports of European automobiles) and the other five have been entertained by the WTO (reformulated gasoline, concerning; shrimp-turtle, beef hormones, Australia salmon, asbestos, dealing with a French ban on imports of Canadian asbestos and products containing asbestos) totally eight GATT and WTO disputes are normally cited as being of most important to environmental issues, though arguments and findings in others are, of course, also important.

ICJ

The ICJ has dealt with a small number of environment-related disputes. In September 1995, up on New Zealand's request to consider the legality of the resumption by France of underground nuclear testing, the Court stated that its order was 'without prejudice to the obligations of States to respect and protect the natural environment' a statement that was at least partly based on the 1992 Rio Declaration.

However, the more significant was the Court's judgment in the case between Hungary and Slovakia in the Gabcikovo-Nagymaros Project, involving the construction of a barrage on the Danube. In its judgment, the court accepted the principle of 'ecological necessity' whereby a state may seek to preclude responsibility for otherwise wrongful acts by invoking the law of state responsibility. ${ }^{1}$

The other case that has significant value regarding environment and endangered spices is the Whaling case ${ }^{2}$ between Australia and Japan in which Australia requests the court to order Japan to refrain from authorizing or implementing any special permit of JARPA II and the court thereby accepts the claim of Australia and decided in its favor.

\section{International Tribunal for the Law of the Sea}

In addition to the sword Fish dispute between Chile and EC as provided above, the tribunal ruled out against Japan in August 1999 for Japan's unilateral of 'experimental' fishery of about 1500 tons in the area covered by the Convention for the Conservation of Southern Bluefin Tuna after protests and request by Australia and New Zealand for 'provisional measures' an interim injunction to prevent the fishery. ${ }^{3}$

\section{Concluding remarks}

The growing global interconnectedness, both in economic and environmental, increases the need for coherence and coordination in trade and environmental policies, rules, and institutions. As international rules in both the trade and environmental fields increase in geographic and substantive scope, promoting the complementary functioning and implementation of these sets of rules as opposed to conflicts among institutions and rules is crucial to achieving sustainable development objectives to which the WTO is destined to ${ }^{4}$.

Though it is provided that both are coordinating each other ${ }^{5}$ a closer cooperation, beyond information exchange and of exchange of documents between MEA Secretariats and WTO Committees is essential to ensure that the trade and environment regimes develop coherently. ${ }^{6}$

\footnotetext{
${ }^{1}$ Ibid page 4

2 ICJ, the Whaling in the Antarctic (Australia v. Japan: New Zealand intervening), Summary 2014/3 31 March 2014

${ }^{3}$ See supra note 35 page 11

${ }^{4}$ See the preamble of WTO

5 See World Trade organization, existing forms of cooperation and information exchange between UNEP and WTO, Committee on Trade and Environment Special Session, TN/TE/S/2/Rev.2 16 January 2007

6 WTO, Environment Negotiations, The Doha mandate on multilateral environmental agreements (MEAs), https://www.wto.org/english/tratop_e/envir_e/envir_neg_mea_e.htm Last Visited 15/9/2019
} 